Сергій Горбачевський, кандидат технічних наук, старший науковий співробітник Національний університет оборони України імені Івана Черняховського, м. Київ

ORCID ID 0000-0002-4946-1604

DOI: $10.33099 / 2617-1775 / 2021-01 / 95-100$

\title{
АВТОМАТИЗАЦІЯ ОБЛІКУ РЕЗУЛЬТАТІВ НАУКОВОЇ ТА НАУКОВО-ТЕХНІЧНОЇ ДІЯЛЬНОСТІ У ВВНЗ
}

Розглянуто шляхи автоматизації обліку наукової та науково-технічної діяльності у ВВНЗ, а також. аналіз нормативної бази, яка визначає основні форми та види наукової та науково-технічної діяльності у вищій школі. Представлена структура автоматизачії обліку баз даних наукової та науково-технічної діяльності у вищих військових навчальних закладах. У статті описано шляхи вдосконалення наукової та науково-технічної діяльності у вищих військових навчальних закладах шляхом запровадження автоматизачії бухгалтерського обліку наукової та науково-технічної діяльності. Запропонована автоматизація покращить якість управлінських рішень та забезпечить легкий та зручний доступ до інформації, щзо зберігається за допомогою різних запитів до бази даних.

Ключові слова: інформачійна система; наукова і науково-технічна діяльність; вищі військові навчальні заклад; автоматизація обліку.

Постановка проблеми. Проблема справедливого розподілу бюджетних коштів на наукову та науково-технічну діяльність (ННТД) потребує рейтингування ВУЗ-ів за результатами наукової діяльності. Тому завдання автоматизації обліку наукової та науково-технічної діяльності у ВВНЗ стає вкрай актуальним. Розвиток інформаційних технологій дає безліч варіантів рішення задачу автоматизації обліку, з яких треба обрати раціональний.

Аналіз публікацій. Питанням автоматизації будь чого присвячені безліч робот [1-3]. В Україні облік НДР, дисертацій та патентів автоматизовано на державному рівні у УкрIHTEI [4]. Для обліку публікацій є свої інформаційні системи - Google Scholar, CrossRef, ORCID та інші.

Метою статті $\epsilon$ аналіз нормативної бази, що визначає основні форми та види наукової та науково-технічної діяльності у ВВНЗ та варіантів автоматизації іiі обліку.

Виклад основного матеріалу. Основними документами, що регламентують наукову та науково-технічної діяльності у ВВНЗ $є$ закон України “Про наукову і науково-технічну діяльність"[5], Наказ Міністерства освіти і науки України №338 від 12.03.2019 “Про державну атестацію закладів вищої освіти в частині провадження ними наукової (науково-технічної) діяльності”[6], Наказ Міністерства оборони №385 від 27.07.2016 “Про затвердження Положення про організацію наукової i науково-технічної діяльності в системі Міністерства оборони України"[7].

Згідно з Наказом Міністерства оборони №385 від 27.07.2016 основними формами наукових та науково-технічних (прикладних) результатів наукової і науково-технічної діяльності є: 
звіти про виконання НДР або іiі складових частин, оперативних завдань, складових частин аванпроектів та ДКР, проектно-конструкторських i технологічних розробок тощо;

експериментальні (дослідні) зразки або їх діюча модель (макет);

ескізні й технічні проекти, конструкторсько-технологічна документація на науково-технічну продукцію;

нові та модернізовані зразки озброєння і військової техніки та їх окремі елементи;

висновки за результатами проведених експертиз науково-технічної та конструкторсько-технологічної документації;

алгоритми, програми, математичні моделі, інформаційні та розрахункові задачі (комплекси задач), інше спеціальне математичне програмне забезпечення;

воєнно-теоретичні праці, монографії, дисертації, настанови, підручники, посібники, статутні документи, національні та військові стандарти, класифікатори та кодифікатори, матеріали наукових конференцій, семінарів, нарад, наукові статті та доповіді, матеріали наукової і науково-технічної експертизи, наукові повідомлення про науково-дослідну роботу;

звіти про дослідження на заходах підготовки та повсякденної діяльності військових організаційних структур;

звіти про патентні дослідження, патентні формуляри, оформлені під час виконання НДР (ДКР);

звіти про впровадження результатів винахідницької та раціоналізаторської роботи;

програми, методики, акти та протоколи випробування нових (модернізованих) зразків озброєння і військової техніки;

проекти нормативно-правових актів, нормативно-технічних документів або методичних рекомендацій, підготовка яких потребує проведення відповідних наукових досліджень або містить наукову складову;

результати інших робіт, пов'язаних 3 одержанням нових наукових i науково-прикладних результатів та впровадженням їх у практику Збройних Сил та Держспецтрансслужби;

розроблені тактико-технічні завдання (далі - ТТЗ), технічні завдання (далі ТЗ) на виконання ДКР.

Виходячи 3 переліку форм ННТД треба перейти до набору показників, за якими обліковується наукова робота. Ці показники мають різну вагу, за якою їх можна проранжувати. I це дасть змогу визначити етапність автоматизації, а крім цього, це може бути використано при рейтингування як окремих науковців, так і наукових підрозділів.

Пропонується такій набор показників:

1. Публікації в наукових виданнях, що включені до баз даних Scopus та/або Web of Science Core Collection

2. Публікації в іноземних наукових виданнях

3. Публікації у фахових наукових виданнях

4. Патенти, авторські свідоцтва, рац. пропозиції 
5. Керівництво науковими (науково-технічними) проектами (розробками), у тому числі НДР (ДКР)

6. Участь у наукових (науково-технічних) проектах (розробках), у тому числі НДР (ДКР)

7. Розроблення (експертиза) проектів нормативно-правових актів i нормативно-технічних документів, методичних рекомендацій

8. Публікації (монографії, підручники, методичні посібники/рекомендації, довідники, електронні навчальні та навчально-методичні посібники, електронні підручники)

9. Рецензування монографій, підручників, статей

10. Доповіді (публікації) на конференціях, симпозіумах, семінарах

11. Проведення досліджень на навчаннях, інших заходах оперативної та мобілізаційної підготовки

12. Проведення мовних тестувань відповідно до стандарту НАТО STANAG 6001

13. Виконання оперативних завдань наукового характеру

14. Консультування докторантів, керівництво ад’юнктами (здобувачами)

15. Участь у роботі спеціалізованих рад

16. Участь у роботі експертних рад $\mathrm{MOH}$

17. Рецензування дисертацій

18. Підготовка відгуків на автореферати дисертацій

19. Опанування дисертаційних робіт

20. Робота у складі комісій Національного агентства із забезпечення якості вищої освіти з акредитації освітніх та освітньо-наукових програм

21. Робота у складі редакційних колегій фахових наукових видань

22. Участь у міжнародних наукових конференціях (форумах, семінарах

Після визначення основних показників, що характеризують наукову i науково-технічну діяльність можна приступати до проектування бази даних.

Проектування бази даних зазвичай проводиться в три етапи. Перший концептуальне або інфологічне проектування. Воно має на увазі під собою опис інформаційних об'єктів (понять предметної області) і зв'язків між ними. Другий етап - логічне (даталогічне) проектування. На цьому етапі створюється схема бази даних на основі конкретної моделі даних, наприклад, реляційної. При цьому описуються типи даних i ïx розмірність. Типи даних та їх розмірність вибираються виходячи 3 можливих запитів до бази даних для формування відповідних довідок і звітів, а також виходячи з можливого розміру реальних даних, які повинна відображати база даних. По можливості база даних повинна містити веб-посилання на опубліковані результати наукової роботи. Ну і фізичне проектування це створення схеми бази даних для конкретної системи управління базою даних (СУБД). Специфіка конкретної СУБД може включати в себе обмеження на найменування об'єктів бази даних, обмеження на типи даних, що підтримуються, і таке інше.

Основними типами даних (полів) для проектування баз даних обліку результатів ННТД $є$ :

char - рядок фіксованої довжини 
varchar - рядок змінної довжини

text - текст довжиною до 64 Кб

int - цілі числа

float - дробові числа з плаваючою комою

date - дата, за замовчуванням формат уууу-mm-dd

time - час, за замовчуванням формат hh:mm:ss

Наприклад, формат запису про публікацію у фаховому віданні може бути таким:

мова (lang, char(2)), автори (authors, varchar), назва (title, varchar), журнал (journal, varchar), piк (year, date), номер (number, int), номер тому (volume number, int), сторінки (pages, int), посилання (url, varchar).

На даний час $є$ три основних варіанта вирішення задачі автоматизації:

за допомогою офісної СУБД Аccess

за допомогою облікових систем типу 1C, Парус або Дебет-Плюс.

за допомогою веб-технологій на базі CMS, наприклад WordPress.

У кожного підходу є свої плюси і мінуси. При виборі варіанта реалізації конкретного варіанту потрібно виходити 3 вимог загальної інформаційної системи, всередині якої працює підсистема обліку результатів ННТД, можливостей наявних ресурсів і таке інше.

На думку автора, використання саме облікових систем $є$ найбільш ефективним варіантом автоматизації обліку результатів ННТД. Наступним етапом робіт має бути впровадження алгоритмів аналітики для забезпечення якості управлінських рішень. Особливістю ННТД у ВВНЗ є бюджетне фінансування та централізоване управління, а тому до автоматизації обліку результатів ННТД може бути застосований єдиний підхід для всіх ВВНЗ. Доречно було би організувати робочу групу або провести НДР з залученням максимального представництва ВВНЗ щодо опрацювання єдиного підходу як для вибору облікових параметрів, так и вибору програмного забезпечення (ПЗ). Програмне забезпечення не обов'язково має бути комерційним, воно може бути i open source. Вдалим прикладом використання open source ПЗ у ВВНЗ може бути використання ПЗ Moodle для платформи дистанційного навчання [8].

Висновки. Розвиток сучасних інформаційних технологій дозволяє перейти до автоматизації обліку результатів ННТД у ВВНЗ. Така автоматизація дозволить як підвищити якість управлінських рішень, так і забезпечити простий і зручний доступ до інформації, що зберігається за допомогою різних запитів до бази даних..

Напрями подальших досліджень пов'язані 3 проведенням пілотного проекту щодо розроблення макету автоматизованої системи обліку результатів ННТД у ВВНЗ.

\section{ЛІТЕРАТУРА}

1. Пономаренко В. С. Інформаційні системи в управлінні персоналом : навч. посібн. / В. С. Пономаренко, І. В. Журавльова, І. Л. Латишева. - Х. : Вид. ХНЕУ, 2008. - 336 с.

2. Пілюшенко В.Л., Шкрабак I.В., Словенко Е.І. Наукові дослідження: організація, методологія, інформаційне забезпечення. - К.: Лібра, 2004. - 344 с. 
3. Шейко В.М., Кушнаренко Н.М. Організація та методика науково-дослідницької діяльності: Підручник. - 2-ге вид., перероб. і доп. - К.: Знання-Прес, 2002. - 295 с

4. Порядок державного обліку НТР та дисертацій http://www.uintei.kiev.ua/page/poryadok-derzhavnogo-obliku-ntr-ta-dysertaciy

5. Закон України "Про наукову і науково-технічну діяльність", https://zakon.rada.gov.ua/laws/show/848-19\#Text

6. Наказ Міністерства освіти і науки України №338 від 12.03.2019 “Про державну атестацію закладів вищої освіти в частині провадження ними наукової (науково-технічної) діяльності", https://zakon.rada.gov.ua/laws/show/z0688-19\#Text

7. Наказ Міністерства оборони №385 від 27.07.2016 “Про затвердження Положення про організацію наукової і науково-технічної діяльності в системі Міністерства оборони України", https://zakon.rada.gov.ua/laws/show/z1172-16

8. Горбачевський С., Орда М., Напрямки використання сучасних технологій в інформаційному забезпеченні системи військової освіти/ Збірник наукових праць "Військова освіта”- №1 (41), - 2020. - С. 103-109.

\section{REFERENCES}

1. Ponomarenko V. S. Informatsiini systemy v upravlinni personalom : navch. posibn. / V. S. Ponomarenko, I. V. Zhuravlova, I. L. Latysheva. - Kh. : Vyd. KhNEU, 2008. - 336 s.

2. Piliushenko V.L., Shkrabak I.V., Slovenko E.I. Naukovi doslidzhennia: orhanizatsiia, metodolohiia, informatsiine zabezpechennia. - K.: Libra, 2004. - 344 s.

3. Sheiko V.M., Kushnarenko N.M. Orhanizatsiia ta metodyka naukovo-doslidnytskoi diialnosti: Pidruchnyk. - 2-he vyd., pererob. i dop. - K.: Znannia-Pres, 2002. - $295 \mathrm{~s}$

4. Poriadok derzhavnoho obliku NTR ta dysertatsii http://www.uintei.kiev.ua/page/poryadokderzhavnogo-obliku-ntr-ta-dysertaciy

5. Zakon Ukrainy "Pro naukovu i naukovo-tekhnichnu diialnist", https://zakon.rada.gov.ua/laws/show/848-19\#Text

6. Nakaz Ministerstva osvity i nauky Ukrainy №338 vid 12.03.2019 "Pro derzhavnu atestatsiiu zakladiv vyshchoi osvity $\mathrm{v}$ chastyni provadzhennia nymy naukovoi (naukovotekhnichnoi) diialnosti", https://zakon.rada.gov.ua/laws/show/z0688-19\#Text

7. Nakaz Ministerstva oborony №385 vid 27.07.2016 "Pro zatverdzhennia Polozhennia pro orhanizatsiiu naukovoi i naukovo-tekhnichnoi diialnosti v systemi Ministerstva oborony Ukrainy", https://zakon.rada.gov.ua/laws/show/z1172-16

8. Horbachevskyi S., Orda M., Napriamky vykorystannia suchasnykh tekhnolohii v informatsiinomu zabezpechenni systemy viiskovoi osvity/ Zbirnyk naukovykh prats "Viiskova osvita”- №1 (41), - 2020. - S. 103-109.

\section{РЕЗЮМЕ}

Сергей Горбачевський, кандидат технических наук, старший научный сотрудник Национальный университет обороны Украины имени Ивана Черняховского

\section{ВВУ3-e \\ Автоматизация учета результатов научной и научно-технической деятельности в}

Рассмотрень пути автоматизачии учета научной и научно-технической деятельности в ВУЗе, а также. анализ нормативной базы, определяющей основные формы и виды научной и научно-технической деятельности в высшей школе. Представлена структура автоматизации учета баз данных научной и научно-технической деятельности в высших военных учебных заведениях. В статье описаны пути совершенствования научной и научно-технической деятельности в высших военных учебных заведениях путем введения автоматизации бухгалтерского учета научной и научно-технической деятельности. Представленная автоматизованая система улучшит качество управленческих решений $u$ 
обеспечит легкий и удобный доступ к информацчии, хранящейся с помощьюю различных запросов к базе данных.

Ключевые слова: информационная система; научная и научно-техническая деятельность; высшие военные учебные заведение; автоматизация учета.

\title{
SUMMARY
}

\author{
Serhii Horbachevsky, \\ $\mathrm{PhD}$ (technical sciences), Senior Researcher \\ National Defence University of Ukraine \\ named after Ivan Chernyakhovskyi
}

\section{Automation of the accounting of the results of scientific and scientific-technical activities in higher military educational institutions}

Introduction. The problem of fair distribution of budget funds for scientific and scientifictechnical activities requires ranking of universities by the results of scientific activities. Therefore, the task of automating the accounting of scientific and scientific-technical activities in higher military education is becoming extremely important. The development of information technology provides many options for solving the problem of accounting automation, from which to choose a rational one.

Purpose - analysis of the regulatory framework, which determines the main forms and types of scientific and scientific-technical activities in higher education and options for automation of its accounting.

Methods: the system of general scientific, theoretical and empirical research special methods, methodological analysis of the problem, systematization and generalization of scientific information concerning the nature and content of certain tasks, monitoring of existing systems were used to solve the set research problems, method of information data processing.

Results. The structure of data base accounting automation of scientific and scientifictechnical activity in higher military educational institutions.

Originality. The article describes ways to improve of scientific and scientific-technical activity in higher military educational institutions by introduction of accounting automation of scientific and scientific-technical activity.

Conclusion. The development of modern information technologies allows to move to the automation of accounting for the results of scientific and scientific-technical activities in higher education. Such automation will improve the quality of management decisions and provide easy and convenient access to information stored through various queries to the database.

Key words: information system scientific and scientific-technical activities; higher military educational institutions; accounting automation. 